\section{CITAÇÃo}

Professor do Ano 2019,

Rev. Ciência Elem., V7(04):063.

10.24927/rce2019.063

\section{EDITOR}

José Ferreira Gomes,

Universidade do Porto

\section{PUBLICADO EM}

17 de dezembro de 2019

\section{COPYRIGHT}

(C) Casa das Ciências 2019.

Este artigo é de acesso livre, distribuído sob licença Creative

Commons com a designação CC-BY-NC-SA 4.0, que permite a utilização e a partilha para fins não comerciais, desde que citado 0 autor e a fonte original do artigo.

\section{rce.casadasciencias.org}

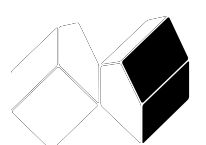

\title{
Professor do Ano 2019
}

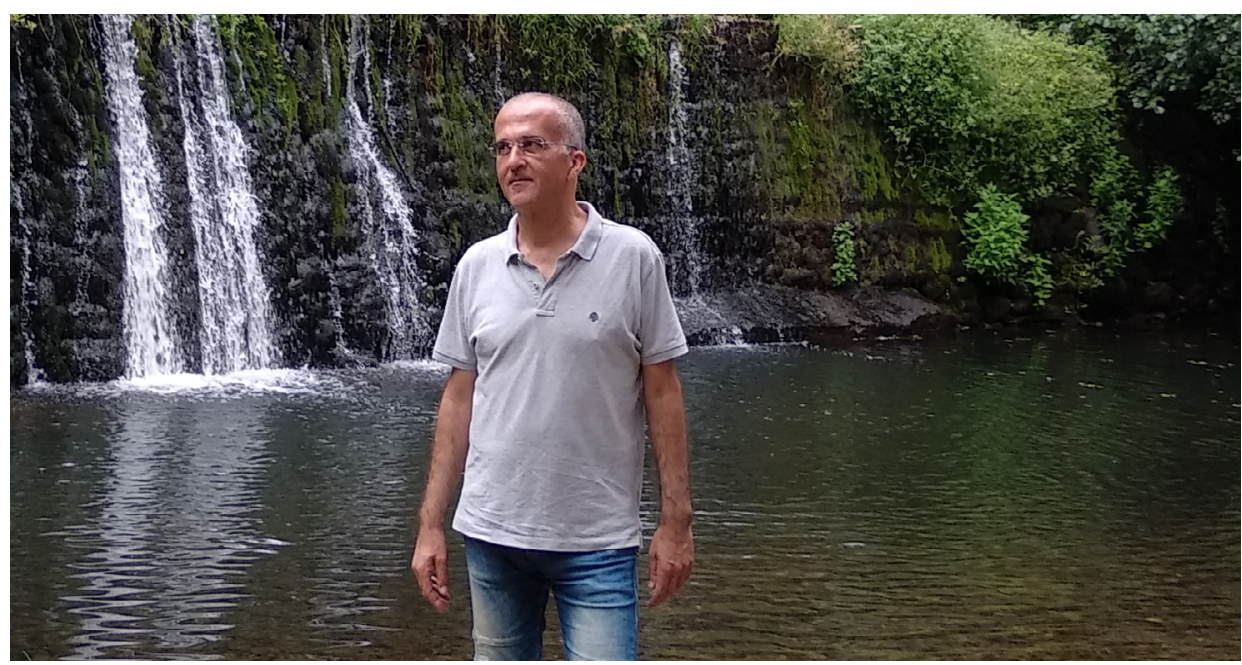

Carlos Portela

É professor de Ciências Físico-Químicas na Escola Secundária Dr. Joaquim de Carvalho, na Figueira da Foz, desde 1992.

Nasceu em Moçâmedes, Angola, em 1966. Reside na Figueira da Foz desde 1992. É licenciado em Física (1990) e mestre em Ensino da Física e da Química (1995), pela Universidade de Coimbra. Exerce atividade letiva nos ensinos básico e secundário desde 1988.

Dinamiza atividades de promoção da ciência (projetos, exposições, feiras de ciência e conferências). Alguns dos seus alunos participaram na International Physics Olympiad e na Olimpíada Ibero-americana de Física. Dinamiza ações de formação para professores desde 1999. Em 2005 foi galardoado com uma menção honrosa no Concurso Rómulo de Carvalho, dinamizado pela Sociedade Portuguesa de Física. É autor de diversos recursos didático-pedagógicos: manuais escolares, livros de apoio para os alunos, livros de apoio para os professores e recursos digitais. É revisor científico-pedagógico de manuais escolares. Mantém o sítio web Vídeos para o Ensino das Ciências (https://sites.google.com/site/videosfq/), onde organiza hiperligações para vídeos nas áreas da matemática, da física e da química. É colaborador da Casa das Ciências (desde 2010). Tem materiais didáticos publicados na Casa das Ciências, alguns deles premiados. Foi coordenador da Divisão de Educação da Sociedade Portuguesa de Física (2011 a 2018).

Integrou a Comissão Nacional das Olimpíadas de Física (desde 2006), Comissão Organizadora da XI Olimpíada Ibero-americana de Física (2006), Comissões Organizadoras e Científicas de Encontros Ibéricos para o Ensino da Física (2011 a 2018), Comissão Editorial 
da Gazeta de Física e Comissão Científica da Olimpíada da Ciência da União Europeia 2019.

Foi membro do Conselho Consultivo do Gabinete de Avaliação Educacional - GAVE (2011 a 2013), do Conselho Científico do Instituto de Avaliação Educativa - IAVE (2013 a 2017) e do respetivo Conselho Geral (2013 a 2018).

Integrou os grupos de trabalho responsáveis pela elaboração de documentos curriculares do ensino básico e secundário, na área da Física e da Química: Metas Curriculares de Ciências Físico-Químicas do 3. CEB (2013), e no secundário, Metas Curriculares e Programa de Física e Química A (10.ำ e 11.ํanos) e Metas Curriculares de Física (12.ํano) (2014); Aprendizagens Essenciais das disciplinas de Ciências Físico-Químicas, Física e Química A e Física 12.ำ dos Cursos Científico-Humanísticos (2018); Aprendizagens Essenciais das disciplinas de Estudo de Movimento e de Física e Química dos Cursos Profissionais (2019).

O ambiente nas aulas não podia ser melhor: estamos atentos, trabalhamos, e aprendemos, mas há também espaço para pequenas brincadeiras, sorrisos e gargalhadas. 0 professor é capaz de chorar de tanto rir!

Ana Romeiro, ex-aluna

Este Professor é respeitado (e vice-versa) e todos sabem que podem contar com o seu apoio quando têm algum problema, tanto na escola como em casa.

Raquel Pina, ex-aluna, 1ํano, IST-ULisboa

Eu gostava de ir às aulas porque gostava do professor e acredito que isso me fazia mais atento e mais recetivo. Fui um privilegiado pela sorte que o colocou no meu caminho.

Bruno Moura, ex-aluno, $3^{\circ}$ ano, IST-ULisboa

Distinguir o Carlos Portela como professor do ano da Casa das Ciências é tão merecido que as palavras servem de pouco.

Maria da Conceição Abreu, presidente, Sociedade Portuguesa de Física

"Professor do Ano" é a distinção atribuída anualmente pela Comissão Editorial da Casa das Ciências a um professor em reconhecimento do seu mérito como docente do ensino básico ou secundário e da sua disponibilidade de partilhar a sua experiência com os colegas. 